\title{
クルクミン改良法による水中の微量ホウ素の定量
}

\section{Analysis of trace amounts of boron in waters using an improved curcumin method}

\author{
北 村 秀 樹* \\ Hideki KITAMURA
}

\author{
杉 前 昭 好* \\ Akiyoshi SUGIMAE
}

\author{
中 本 雅 雄* \\ Masao NAKAMOTO
}

\begin{abstract}
An improved curcumin method has been developed using a 20\% (v/v) 2-ethyl-1,3-hexanediol, a boron complexing agent, in diisobutyl ketone as an extracting solvent. Boron in the upper, organic solvent is converted to rosocyanin complex by the addition of glacial acetic acid-curcumin solution (0.375\%) and concentrated sulfuric acid in this order. The concentrate is diluted with $95 \%$ ethanol and spectrophotometrically read at $550 \mathrm{~nm}$ vs. ethanol. Beer's law is obeyed over the concentration range of $0.02(\mathrm{cell}: 5 \mathrm{~cm})-10(\mathrm{cell}: 1 \mathrm{~cm}) \mathrm{mg} \mathrm{B} / 1$, and relative standard deviations for blank and $1 \mathrm{mg} \mathrm{B} / 1$ solutions are $c a .2$ and $0.9 \%$, respectively. The improved curcumin method eliminates inconvenient time limits and the interferences of hardening agents, iron(III), fluoride and nitrate. This method with or without alkali fusion as a pretreatment was applied to the determination of boron in industrial waste water, disposal plant sewage, river water and sea water. The results obtained by this method were in good agreement with those obtained by a modified curcumin method and ICP-atomic emission spectrophotometry. When boron in a sample solution such as industrial waste water exists in the chemical form of fluoroborate, etc., the pretreatment of alkali fusion followed by this method must be carried out.
\end{abstract}

Key words: boron, 2-ethyl-1, 3-hexanediol, diisobutyl ketone, curcumin, water sample

\section{1. 緒言}

ホウ素は河川水に世界の平均で $13 \mu \mathrm{g} / 1^{11}$, 海水に 4

〜 $5 \mathrm{mg} / 1$ 程度 ${ }^{2)}$ 含まれている。しかしながら, 近年工

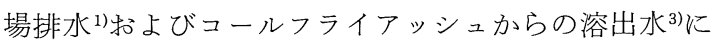
よるホウ素の污染がみられ, 農業の灌溉用水などにホ ウ素が増加し, 問題となっている。そこで, ルーチン 分析に適した簡易で高感度なホウ素の分析法の開発が 要望されている。水中のホウ素の定量法としては，炎 光法4), 原子吸光法5,6), ICP 発光分析法7 99 抢よび比色 法10 26)がある。比色法に比べて前二者は感度が悪いが, ICP 発光分析法は高感度で妨害も少なく，著者らも排 水拉よび環境水に適用し，良好な結果を得ているが9， 機器が高価なため一般的でない。一方, 比色法として は従来からメチレンブルー法 ${ }^{10)}$ が行われ，公定法 ${ }^{11}$ と して採用されているが, 操作が煩雑でブランクの吸光 度が高く，またバラッキが大きいといら欠点がある。 さらに，最近比色法としてホウ素錯アニオンと大きな
発色団をもつカチオンとのイオン対抽出を利用する方 法 ${ }^{12)} \alpha$-ジオールや $\alpha$ 一ヒドロキシ酸を錯化郕とし て用いる抽出吸光光度法 ${ }^{13}$ が行われているが，試薬が 入手困難など問題がある。

他方，以前からよく使用されているクルクミンを用 いる比色法がある。この方法は次の 2 つのグループに 大別される。第 1 は, 従来から行われているルブロク ルクミン錯体を作る方法 ${ }^{10,14)}$, 第 2 はロゾシアニン錯 体 (ホウ素：クルクミン=1：2）を作る方法15 23) (以 後, クルクミン変法といら）がある。前者は後者に比 べて約半分の分子吸光係数であり，蒸発乾固などで時 間がかかり，妨害が多いといら欠点がある ${ }^{19)}$ 。Hays 拉 よび Metcalfe ${ }^{18)}$ が発展させたクルクミン変法は強い 硫酸酸性下で水をほとんど含まない溶液中でホウ素と クルクミンとを反応させる方法であり，その反応は次 のと抢りである20,211。クルクミンを $\mathrm{H}_{3} \mathrm{~A}$ とすると

* 大阪府公害監視センター テ537 大阪市東成区中道 1-3-62, Environmental Pollution Control Center, Osaka Prefectural Government, 62-3-1, Nakamichi, Higashinari-ku, Osaka-shi, Osaka 537 Japan 
$\mathrm{H}_{3} \mathrm{~A}+\mathrm{H}^{+} \rightleftarrows \mathrm{H}_{4} \mathrm{~A}^{+}$

$2 \mathrm{H}_{4} \mathrm{~A}^{+}+\mathrm{B}(\mathrm{OH})_{3} \rightleftarrows \mathrm{B}\left(\mathrm{H}_{2} \mathrm{~A}\right)_{2}^{+}+3 \mathrm{H}_{2} \mathrm{O}+\mathrm{H}^{+} \cdots(2)$

$\mathrm{B}\left(\mathrm{H}_{2} \mathrm{~A}\right)_{2}^{+}+\mathrm{HSO}_{4}^{-} \rightleftarrows \mathrm{B}\left(\mathrm{H}_{2} \mathrm{~A}\right)_{2}^{+} \cdot \mathrm{HSO}_{4}^{-}$

(2)の反応はクルクミンをプロトン化することにより 進行し，(2)式より水分を多く含むとロゾシアニン錯体 が生成しにくい。また末反応のプロトン化したクルク ミン $\left(\mathrm{H}_{4} \mathrm{~A}^{+}\right)(555 \mathrm{~nm}$ に吸収極大）はロゾシアニン錯 体（550nm に吸収極大）の吸光度を測定する際妨害と なるので，妨害しない形 $\left(\mathrm{H}_{3} \mathrm{~A}\right) （ 420 \sim 430 \mathrm{~nm}$ に吸収 極大）に脱プロトン化される20)。Goldman ら ${ }^{16)}$ 打よび Mair ${ }^{17)}$ は 2-エチル-1.3-ヘキサンジオール（以 下 EHD と略記）ークロロホルム溶液でホウ素を抽出 し, 抽出液の一部にクルクミン一酢酸溶液掞よび濃硫 酸を加え, ロゾシアニン錯体を生成させ, $95 \%$ エタノー ルで希釈する方法を確立し, 水中㧊よび動物組織中の ホウ素の定量に適用した。著者らもこの方法について 詳細に検討し, 工場排水㧍よび海水に適用した ${ }^{22)}$ 。しか しながら，この方法では下層のクロロホルム相を分取 する際，水を取り込む恐れがあり，バラッキの原因と なる。そこで, $\mathrm{EHD}$ なソブチルメチルケトン (MIBK) を抽出溶媒として用いるクルクミン変法の改 良法が Choiらにより開発された ${ }^{23)}$ 。しかしながら， MIBK に水が $1.9 \%\left(25^{\circ} \mathrm{C}\right)$ 溶解 ${ }^{24)}$ するため, (2)式の反 忘が阻害され, 分子吸光係数が従来の報告值 ${ }^{18)}$ より さい值を示している。また，彼らは100\%エタノールで 希釈することにより，未反応の $\mathrm{H}_{4} \mathrm{~A}^{+}$の脱プロトン化 をしているが，脱プロトン化反応が遅いため，吸光度 の経時変化がみられている。そこで著者らは, クルク ミン変法によりホウ素を精度よく, 高感度に分析する ために，蒸気圧が低く，人体に害の少ない，乙かも水 との相互溶解の少ないジイソブチルケトン (DIBK)を 抽出溶媒として用い24)，希釈液として95\%ェタノール を用いる改良法（以下クルクミン改良法といら）につ いて，基礎的測定条件，共存物質の影響などについて 詳細に検討したので報告する。

\section{2. 実験}

\section{1 試 薬}

$100 \mathrm{mg} / 1$ ホウ素標準原液执よび標準溶液：オルト ホウ酸 $0.572 \mathrm{~g}$ を水に溶解し 11 とし, 標準原液を調製 する。この原液を適宜水で希釈して標準溶液を調製す る $^{22)}$ 。

20\%（v/v）EHD一DIBK 溶液：EHD100ml を分取 し, DIBK で $500 \mathrm{ml}$ とした。この溶液は冷暗所に保存し て用いた。

$0.375 \%(\mathrm{w} / \mathrm{v})$ クルクミン一酢酸溶液: 既報 ${ }^{22)}$ の 抢り調製した。この溶液は使用のつど作った。
濃硫酸：測定条件の検討については和光純薬製有害 元素測定用を用いた。また，検量線，再現性などの検 討についてはメルク社製 Suprapur ${ }^{\circledR} を$ 用いた。

$1 \mathrm{~N}$ 塩酸溶液：メルク社製 Suprapur ${ }^{\circledR} 30 \%$ 塩酸を 水で10倍に希釈して調製した。

その他の試薬は市販特級品を用いた。

使用した純水はステンレス製釜で蒸留し，イオン交 換した水である。

\section{2 装置および器具}

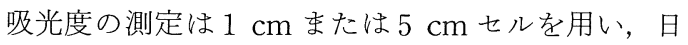
立製200-20型分光光度計を使用して行った。

抽出時, 容器はねじ栓付 $10 \mathrm{ml}$ ポリエチレン製試験管 を用いた。

\section{3 分析方法 \\ 2.3 .1 前処理}

有機物などの浮遊物質が多い試料执よびホウ素が フッ化物となっている試料については，分析に先立ち 次のアルカリ融解を行ら11)

試料水 $25 \mathrm{ml}$ を白金ルツボにとり, 無水炭酸ナトリウ ム $0.1 \mathrm{~g}$ を加光, ホットプレート上で徐々に蒸発乾固 する。次に数分間アルカリ融解したのち, 水約 $15 \mathrm{ml}$ 加光, 加温して固型物を溶解する。 $1 \mathrm{~N}$ 塩酸で中和し, ポリプロピレン製試験管に移して水で $25 \mathrm{ml}$ とする。

\subsection{2 ホウ素の分析}

試料水または前処理した試験溶液 $1 \mathrm{ml}(\mathrm{B} \leqq 10 \mu \mathrm{g})$ を $10 \mathrm{ml}$ ポリエチレン製試験管に分取し， $1 \mathrm{~N}$ 塩酸 2 $\mathrm{ml}$ を加え混合する。次に $20 \%(\mathrm{v} / \mathrm{v}) \mathrm{EHD}$-DIBK 溶 液 $3 \mathrm{ml}$ を添加し, 2 分間振とうする。静置して層分離 したのち，上層の DIBK 相 $0.5 \mathrm{ml} 25 \mathrm{ml}$ ポリプロピ レン製試験管に分取する。 $0.375 \%(\mathrm{w} / \mathrm{v})$ クルクミン 一酢酸溶液 $1 \mathrm{ml}$, 濃硫酸 $0.3 \mathrm{ml}$ をそれぞれ添加し, 混 合することによりホウ素とクルクミンとを反応させ る。15分後，95\%エタノールを加光， $25 \mathrm{ml}$ とする。約 15分放置後, $550 \mathrm{~nm}$ で95\%エタノールを対照として吸 光度を測定する。

\section{3. 結果と考察}

\section{1 分析条件と検討}

特に断らない限り, 分析条件の検討はホウ素 5 $\mathrm{mg} / 1$ で行った。

\section{1 .1 抽出条件}

ホウ素は EHD と弱い錯体を作り，クロロホルム4),

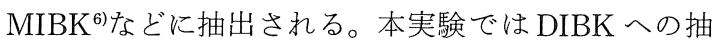
出について検討した。

\subsection{1.a 振とう時間}

$\mathrm{EHD}$ ークロロホルム溶液へのホウ素の抽出の場合, 15 秒以上で十分ホウ素が抽出された ${ }^{22)}$ 。そこで15秒か 
ら 3 分の範囲で振とうしたところ，30秒以上で一定の 吸光度が得られた。従って, 本法では 2 分間振とうす ることとした。

\subsection{1.b 塩酸濃度}

著者らはすでに EHD一クロロホルム溶液によるホ ウ素の抽出に拀いて，0.25〜 6.5N の濃度の酸を添加 することにより定量的にホウ素が抽出されることを見 出した ${ }^{22)}$ 。Choi ら ${ }^{23)}$ は EHD一MIBK 溶液を用いた場 合, $1 \mathrm{~N}$ の塩酸を添加している。そこで $\mathrm{EHD}-\mathrm{DIBK}$ 溶液を用いた場合に添加する塩酸濃度の影響につい て，0.2 $5 \mathrm{~N}$ の範囲で検討した（Fig. 1$)$ 。試料水の 場合, ブランクの吸光度を差し引いた正味の吸光度 (以下 Net-Abs とよぶ)は0.2〜 $1 \mathrm{~N}$ の間で若干増加す るが，泳ぼ一定であった。 Mair ら ${ }^{17)}$, Goldman ら ${ }^{16)}$ よびChoi ら ${ }^{23}$ 並びに既報22) と従い $1 \mathrm{~N}$ 塩酸 $2 \mathrm{ml}$ を 添加することとした。な扔，より低濃度のホウ素を定 量する場合, 試料水 $2 \mathrm{ml}$ を分取し, $2 \mathrm{~N}$ 塩酸 $1 \mathrm{ml}$ 添

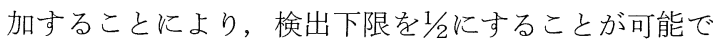
ある。

\subsection{1.c $\mathrm{DIBK}$ 中の $\mathrm{EHD}$ 濃度}

DIBK 中の $\mathrm{EHD}$ 濃度の影響を 1 〜 $20 \%(\mathrm{v} / \mathrm{v})$ の範 囲で検討した。(Fig. 2)。EHD 濃度の増加に伴ない 10\%末では徐々にNet-Abs が増加するが，10\%以上 で注淁一定となる。ブランクの吸光度は 5 ～20\%の間 で一定であった。EHDークロロホルム溶液を用いた場 合， 2 20\%の範囲の EHD でホウ素が完全に抽出さ れており先,22), DIBK はクロロホルムに比べてホウ素が 抽出されにくいことが分かる。Choi ら ${ }^{23}$ は

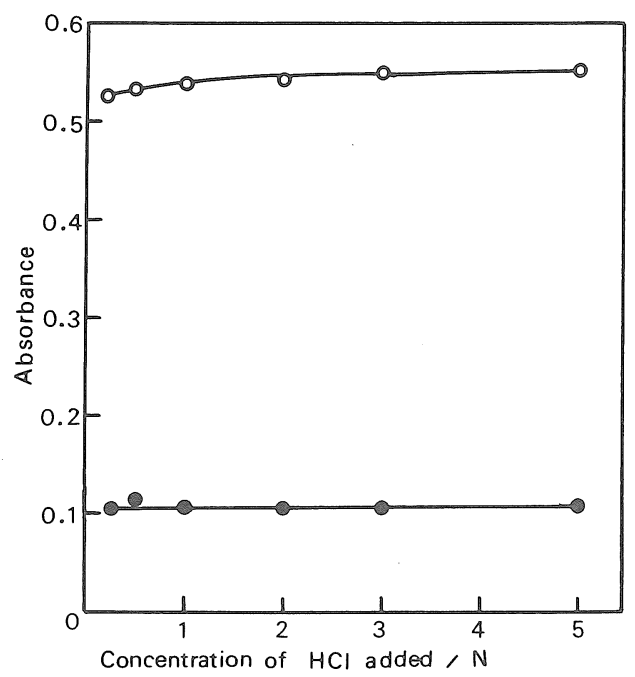

Fig. 1 Effect of concentration of hydrochloric acid added on the extraction of boron.

[boron]/mg $1^{-1}:-0,-\bigcirc-5$; Absorbance : - - vs. ethanol, $-\bigcirc-$ net (-blank absorbance).

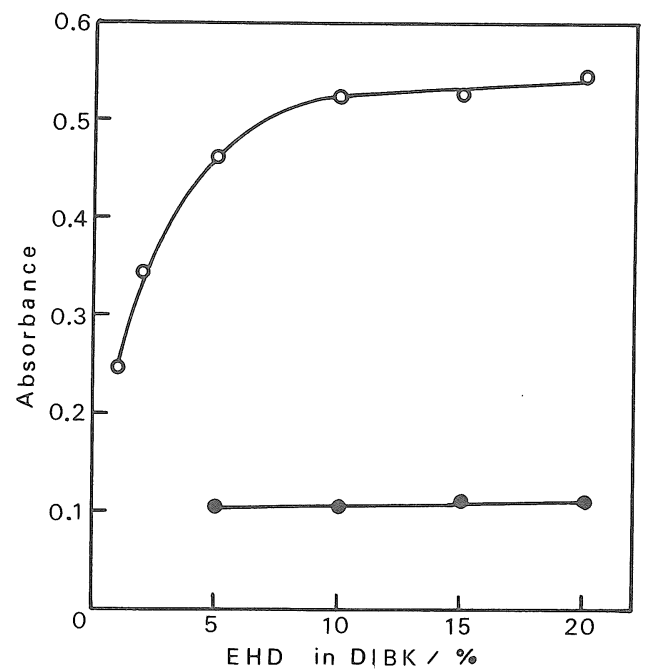

Fig. 2 Effect of concentration of EHD in DIBK on the extraction of boron. Concentration of boron and absorbance are the same as those in Fig. 1 .

一MIBK 抽出の際，20\%の EHD を用いて扣り，本法 に执いても EHD 濃度を $20 \%$ とした。

\section{1 .2 ロゾシアニン錯体の生成条件}

ロゾシアニン錯体生成反応（1打よび 2 式）は発熱 反応であるが，室温に放置して反応させた。

\subsection{2.a クルクミンの添加量}

$0.375 \%(\mathrm{w} / \mathrm{v})$ クルクミン一酶酸溶液の添加量の影 響について, 0.5〜2ml の範囲で検討した結果を Fig. 3 に示す。0.5〜 $1 \mathrm{ml}$ の間で若干 Net-Abs が増加した が, $1 \mathrm{ml}$ 以上で一定值を示した。そこで, $0.375 \%$ (w／ v）クルクミン一酢酸溶液を $1 \mathrm{ml}$ 添加することとし $た^{16,17,22,23)}$ 。また，ブランクの吸光度がクルクミンの添 加量の増加に伴ない徐々に増加するので, 正確に添加 する必要がある。

\subsection{2.b 濃硫酸の添加量}

ロゾシアニン錯体生成にお壮る濃硫酸の添加量の影 響を0.1〜0.5ml の範囲で調べた。Fig.4にみられるよ らに, Net-Abs は濃硫酸の添加量が $0.2 \sim 0.5 \mathrm{ml}$ の間 で注ぼ一定であった。そこで濃硫酸を $0.3 \mathrm{ml}$ 添加する こととした ${ }^{16,17,22)}$ 。また, 濃硫酸の添加量の増加に伴な いブランクの吸光度が直線的に増加することから, 濃 硫酸を正確に添加する必要がある。

\subsection{2.c 反応時間}

ロゾシアニン錯体生成にお打る反応時間（濃硫酸添 加後，エタノールで希釈するまでの時間）の影響につ いて検討を行った(Fig.5)。1 拉よび $5 \mathrm{mg} / 1$ のホウ 素溶液とも反応時間が 10 分までは急激に吸光度が増加 し，10分以上で吸光度が最大かつ一定となった。これ は10分以上の反応でロゾシアニン錯体が定量的に生成 


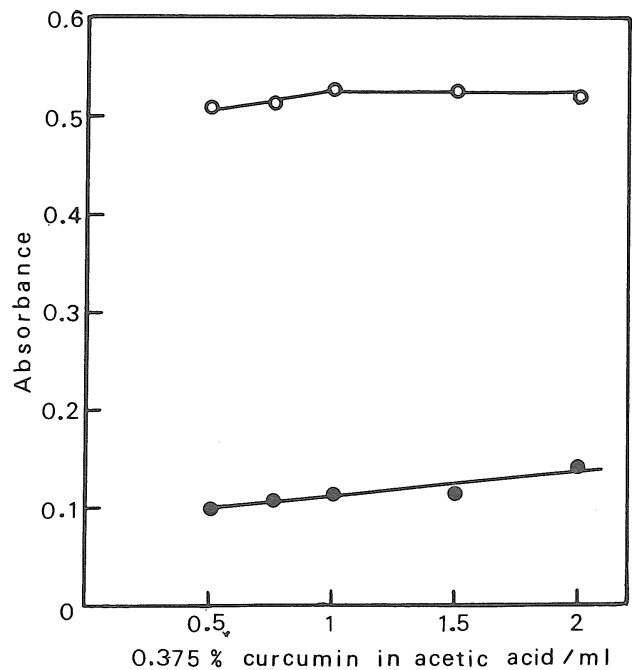

Fig. 3 Effect of curcumin on the formation of rosocyanin complex.

Concentration of boron and absorbance are the same as those in Fig. 1.

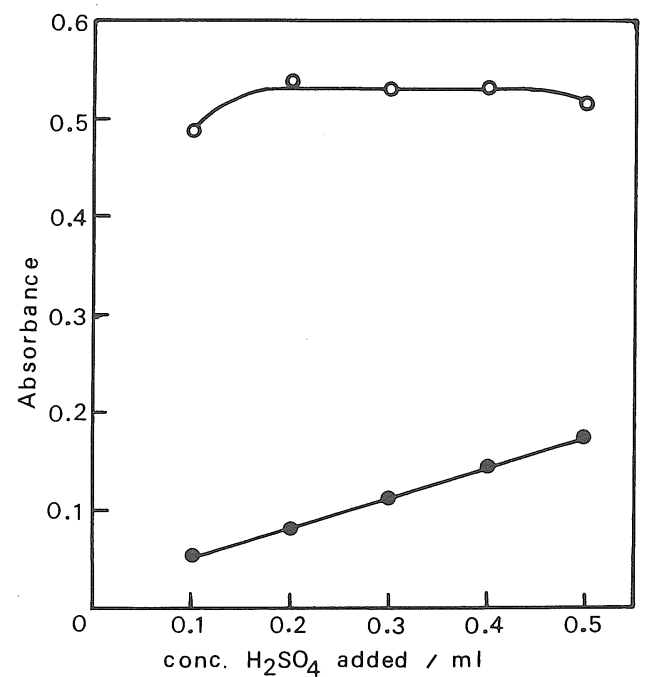

Fig. 4 Effect of sulfuric acid on the formation of rosocyanin complex.

Concentration of boron and absorbance are the same as those in Fig. 1 .

することを示している。ぬた，ブランクの吸光度は反 応時間に無関係に一定であった。そこで，濃硫酸添加 後，15分間放置してホウ素とクルクミンとを反応させ ることとした。

\section{1 .3 放置時間}

ロゾシアニン錯体を生成させたのち，エタノールに よる希釈後の吸光度の連続的な経時変化を Fig. 6 に 示す。 $99.5 \%$ エタノールで希釈した場合，ブランクお よび試料溶液ともそれぞれ吸光度が平行して減少して

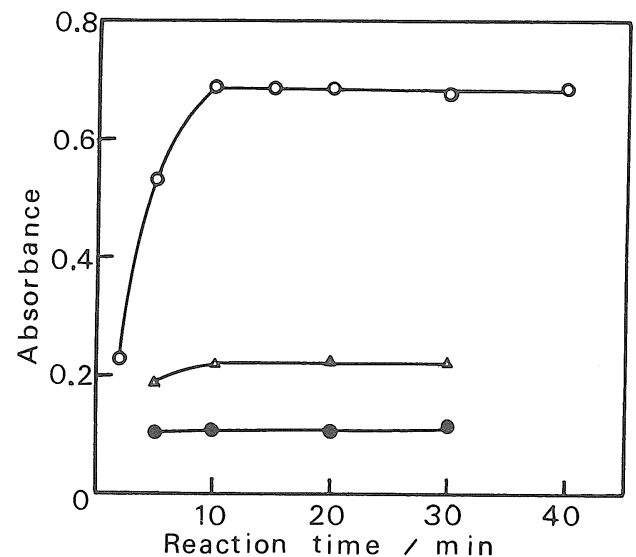

Fig. 5 Effect of reaction time on the formation of rosocyanin complex.

[boron]/mg 1 ${ }^{-1}:-\bigcirc-0,-\triangle^{-1},-\bigcirc^{-} 5$; Absorbance: vs. ethanol.

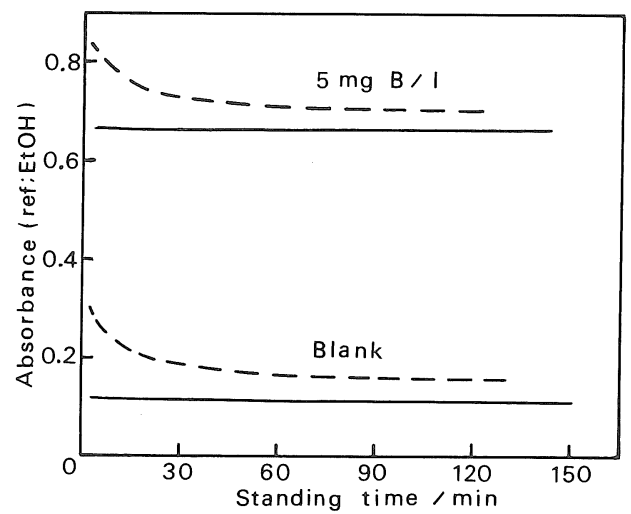

Fig. 6 Effect of standing time after dilution with ethanol on absorbance.

Ethanol : - 95\%,--- 99.5\%; Absorbance : vs. ethanol.

いる。これは希釈後, 徐々にプロトン化したクルクミ ン $\left(\mathrm{H}_{4} \mathrm{~A}^{+}\right)$が中性型 $\left(\mathrm{H}_{3} \mathrm{~A}\right)$ に解離するが，ロゾシア ニンは安定に存在することを示しているものと考えら れる ${ }^{22,23)}$ 。しかしながら，95\%エタノールで希釈した場 合, 数分以上でほぼ一定の吸光度を示して扣り, 脱プ ロトン化反応がかなり早く進行するものと思われ る ${ }^{22)}$ 。Choi ら ${ }^{23)}$ は100\%エタノールで希釈し，バラッキ をなくすため希釈後60分で吸光度を測定しているが， 多数の試料を分析するときは，放置時間を一定に保つ ことが困難である。従って, 本法では95\%エタノールで 希釈し, 希釈後15分以降で吸光度を測定することとし $た^{16,17,22)}$ 。

以上の検討の結果, 2.3.2の方法によりホウ素を分析 することとした。

\section{2 ロゾシアニン錯体の安定性}


生成したロゾシアニンは非常に安定で, Uppström ${ }^{199}$ は5 日後で約 $10 \%$, 著者ら ${ }^{22)}$ はクルクミン変法に拈い て24時間後で $4 \%$ しか吸光度が減少しないことを見出 した。本法に抽いても吸光度が 20 時間後で $1.3 \%$, 約 3 日後で $5 \%$ しか減少しておらず, ロゾシアニン錯体が安 定に存在することが確められた。

\section{3 共存物の影響}

ルブロクルクミン錯体を生成させる従来のクルクミ ン法 ${ }^{17)}$ の場合, カルシウム, マグネシウム, 鉄などの金 属塩，さらにフッ化物イオン，硝酸イオンが妨害する ことが知られている10)。そこで, 本法に対するこれらの 共存物の影響について検討した。Table 1 亿示したよ らに, ホウ素 $3 \mu \mathrm{g}$ を含む溶液に対して，カルシウム， マグネシウムは $2000 \mu \mathrm{g}$ 末で，鉄(III) イオンは $50 \mu \mathrm{g}$ 李 で，フッ化物イオンは $20 \mu \mathrm{g}$ まで影響がみられなかっ た。また硝酸イオンについては, ホウ素 $1 \mu \mathrm{g}$ を含む溶 液に対して $5000 \mu \mathrm{g}$ まで影響がみられなかった。

\section{4 検量線，再現性および検出下限}

$0 \sim 2 \mathrm{mg} / 1(5 \mathrm{~cm}$ セル)の範囲のホウ素の標準溶 液について, 検量線は Fig. 7 亿示すように原点を通る 良好な直線関係が得られ, ベールの法則に従らことが 分かる。この検量線の傾きから求めた本法のみかけの $\varepsilon$ (分子吸光係数) は 169000 であり，ロゾシアニン錯体に ついての $\varepsilon$ 值 $(180000)^{18,20)}$, クルクミン変法について の $\varepsilon$ 值 $(175000)^{22)}$ より若干 $(3 \sim 6 \%)$ 低いが，棌淁 同程度であった。MIBKを用いるクルクミン改良法 ${ }^{23}$

Table 1 Effect of diverse ions on the determination of $3 \mathrm{mg} / 1$ boron

\begin{tabular}{ccrc}
\hline $\begin{array}{c}\text { Diverse } \\
\text { ions }\end{array}$ & $\begin{array}{c}\text { Compounds } \\
\text { added }\end{array}$ & $\begin{array}{c}\text { Conc./ } \\
\mathrm{mg} / 1\end{array}$ & $\begin{array}{c}\text { Relative } \\
\text { absorbance }\end{array}$ \\
\hline $\mathrm{Ca}(\mathrm{II})$ & $\mathrm{CaCl}_{2}$ & 100 & 1.006 \\
& & 500 & 1.028 \\
& & 1000 & 1.003 \\
$\mathrm{Mg}(\mathrm{II})$ & $\mathrm{MgCl}_{2}$ & 2000 & 1.009 \\
& & 100 & 0.981 \\
& & 500 & 1.003 \\
$\mathrm{Fe}(\mathrm{III})$ & $\mathrm{FeCl}_{3}$ & 1000 & 1.009 \\
& & 5000 & 0.997 \\
& & 10 & 1.013 \\
$\mathrm{~F}^{-}$ & $\mathrm{NaF}^{-}$ & 50 & 0.991 \\
& & 5 & 0.991 \\
& & 10 & 0.994 \\
$\mathrm{NO}_{3}{ }^{-}$ & $\mathrm{KNO}_{3}$ & 20 & 0.999 \\
& & 10 & $1.007^{\text {a) }}$ \\
& & 100 & $1.007^{\text {a) }}$ \\
& & 1000 & $0.989^{\text {a) }}$ \\
& & 5000 & $0.989^{\text {a) }}$ \\
\hline
\end{tabular}

a) Relative value to absorbance of $1 \mathrm{mg} / \mathrm{l}$ boron

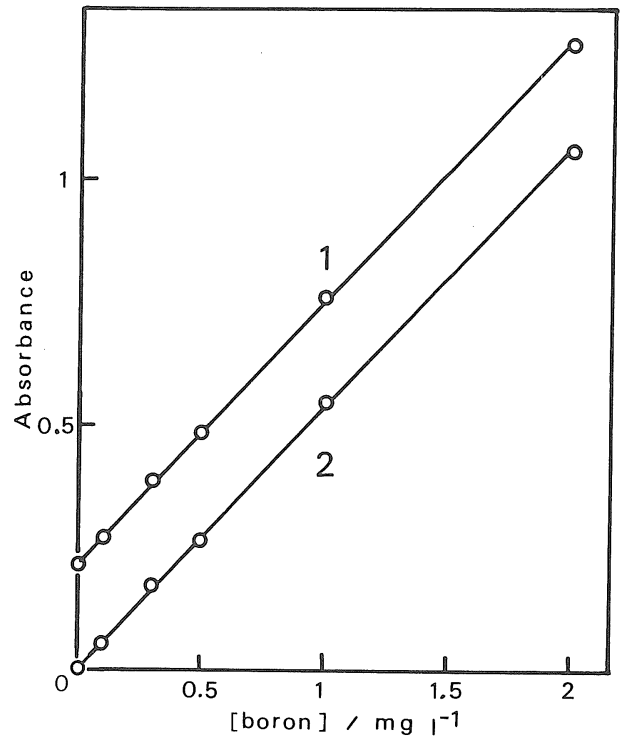

Fig. 7 Calibration curve for boron. Absorbance (cell : $5 \mathrm{~cm}): 1)$ vs. ethanol, 2) net (-blank absorbance).

の場合, みかけの $\varepsilon$ が133000であり, クロロホルムを 用いるクルクミン変法 ${ }^{22} に$ 比べて $24 \%$ ，本法に比べて 22\%低い值である。これはMIBKを抽出溶媒として用 いた場合クロロホルム拈よびDIBKを用いた場合に 比べて，ホウ素の抽出率招よびホウ素とクルクミンと の反応率が悪いためと考光られる。従って, DIBKを用 いる本法の場合, MIBK を用いるクルクミン改良法 ${ }^{23)}$ より高感度にホウ素が定量できる。

$1 \mathrm{~cm}$ 拈よび $5 \mathrm{~cm}$ セルを用いてブランクおよび.1 $\mathrm{mg} / 1$ 標準溶液について 7 回平行測定を行い, 本法に ついての再現性を検討した。Table 2 に示したように, 両者のセルとも変動係数はブランク溶液で約 $2 \%, 1$ $\mathrm{mg} / 1$ 標準溶液で $0.9 \%$ 程度であり, 本法によりホウ素 が精度よく分析できることが分かった。な招，濃硫酸に 市販の有害元素測定用を用いると, ブランク溶液の吸 光度が $0.548(5 \mathrm{~cm}$ セル) と高く, 高純度の試薬を用

Table 2 Precision test on standards

\begin{tabular}{|c|c|c|c|c|}
\hline $\begin{array}{l}\text { Boron }^{\text {a) }} \\
(\mathrm{mg} / \mathrm{l})\end{array}$ & $\begin{array}{l}\text { Cell } \\
\text { length } \\
(\mathrm{cm})\end{array}$ & Abs. ${ }^{b)}$ & $\mathrm{SD}$ & $\begin{array}{l}\text { RSD } \\
(\%)\end{array}$ \\
\hline \multirow{2}{*}{0 (blank) } & 1 & \multicolumn{2}{|c|}{$0.0456 \pm 0.00098$} & 2.14 \\
\hline & 5 & \multicolumn{2}{|c|}{$0.2137 \pm 0.00550$} & 2.57 \\
\hline \multirow{2}{*}{1} & 1 & \multirow{2}{*}{\multicolumn{2}{|c|}{$\begin{array}{l}0.1569 \pm 0.00146 \\
0.7633 \pm 0.00745\end{array}$}} & 0.93 \\
\hline & 5 & & & 0.98 \\
\hline
\end{tabular}

a) Standard solution

b) Absorbance $v s$. ethanol, average of 7 replicates. 
いるよらに注意すべきである。

検出下限（バックグランドのノイズレベル（吸光度 $0.0034) の 3$ 倍の吸光度0.01を示寸ホウ素の濃度) ${ }^{23)}$

Table 2 の標準溶液の吸光度から求めた值として $0.018 \mathrm{mg} / 1$ (5 cm セル) であった。な打抽出時に 2 $\mathrm{N}$ 塩酸を添加すると, 約 $0.01 \mathrm{mg} / 1$ まで検出可能とな る。

\section{5 海水からの回収率}

沿岸海水にホウ素を 3 扣よび $5 \mathrm{mg} / 1$ 添加したと きの回収実験を行った結果をTable 3に示す。それ ぞれ回収率は101〜 102\%と良好で，本法により海水中 のホウ素が十分定量できることが判明した。

\section{6 実試料の分析}

工場排水，下水処理場の処理水，河川水执よび海水 について, No. 5B ろ紙によるろ過执よびアルカリ融解 (海水を除く) し, 本法, クルクミン変法 ${ }^{22}$ 执よび ICP 発光分析法99の三者でホウ素を分析したときの結果を Table 4に示す。三者の分析法間で低濃度の河川水 （No.6）で若干のバラッキがみられるが，各試料水に ついて比較的良好な一致がみられた。しかしながら，

No. 1 の工場排水（ホウフッ化物製造工場）について は，万過した試料水に対する本法执よびクルクミン変 法 ${ }^{22)}$ の分析值が他の分析值の約半分である。これは,

No. 1 の排水中のホウ素が一部フッ化物となってお り，アルカリ融解しないと比色法では検出されなかっ たものと考えられる。

以上のことから，通常の排水打よび環境水中のホウ 素は可溶性の形で存在して扣り，アルカル融解せず本 法で十分定量できることが判明した。また，工場排水 については，ホウ素がフッ化物として存在している場 合があるので，本法に先立らアルカリ融解が必要であ るものと思われる。

\section{4. 終 クに}

$\mathrm{EHD}$ 一DIBK 溶液を抽出液として用いるクルクミ ン改良法について基礎的分析条件の検討を行い, 分析方 法を確立した。本法では，生成したロゾシアニン錯体 が安定で, 吸光度の経時変化がみられなかった。また, 本法では金属類, 硝酸イオン, フッ化物イオンの妨害

Table 3 Recovery of boron from sea water

\begin{tabular}{ccccc}
\hline No. & $\begin{array}{c}\text { Added } \\
(\mathrm{mg} / \mathrm{l})\end{array}$ & $\begin{array}{c}\text { Found } \\
(\mathrm{mg} / \mathrm{l})\end{array}$ & $\begin{array}{c}\text { Re c o- } \\
\text { vered } \\
(\mathrm{mg} / \mathrm{l})\end{array}$ & $\begin{array}{c}\text { Recovery } \\
(\%)\end{array}$ \\
\hline 1 & 0 & 4.08 & - & - \\
2 & 3 & 7.13 & 3.05 & 101.8 \\
3 & 5 & 9.14 & 5.06 & 101.1 \\
\hline
\end{tabular}

Duplicates measurements
Table 4 Analytical results of boron in various waters by improved curcumin method (ICM), modified curcumin method $(\mathrm{MCM})^{22)}$ and inductively coupled plasma-atomic emission spectrophotometry (ICP-AES) ${ }^{9)}$

\begin{tabular}{cllllllll}
\hline \multirow{2}{*}{ No. } & \multicolumn{3}{c}{ Filtrate(No.5B) } & & \multicolumn{3}{c}{ Alkali fusion } \\
\cline { 2 - 3 } \cline { 6 - 7 } & & ICM & MCM & ICP-AES & & ICM & MCM & ICP-AES \\
\hline 1 & 0.056 & 0.056 & 0.12 & & 0.11 & 0.10 & 0.10 \\
2 & 0.60 & 0.69 & 0.72 & & 0.69 & 0.63 & 0.66 \\
3 & 0.034 & 0.046 & 0.043 & & 0.037 & 0.044 & 0.044 \\
4 & 0.046 & 0.051 & 0.049 & & 0.039 & 0.045 & 0.045 \\
5 & 1.0 & 1.1 & 1.2 & & 0.99 & 0.96 & 0.95 \\
6 & 0.019 & 0.015 & 0.022 & & 0.026 & 0.023 & 0.028 \\
7 & 0.096 & 0.094 & 0.095 & & 0.095 & 0.084 & 0.093 \\
8 & 0.089 & 0.095 & 0.095 & & 0.094 & 0.088 & 0.093 \\
9 & 1.0 & 1.1 & 1.1 & & 1.1 & 1.1 & 1.0 \\
10 & 4.3 & 4.3 & 4.5 & & - & - & - \\
11 & 4.0 & 4.0 & 3.9 & & - & - & - \\
12 & 4.4 & 4.3 & 4.2 & & - & - & - \\
13 & 3.6 & 3.5 & 3.6 & & - & - & - \\
14 & 3.9 & 3.9 & 3.8 & & - & - & - \\
15 & 3.8 & 3.9 & 3.7 & & - & - & - \\
\hline
\end{tabular}

Unit : $\mathrm{mg} / \mathrm{l}$

No.1,2: Industrial waste water, No.3-5: Disposal plant sewage, No.6-9: River water, No.10-15: Sea water がみられなかった。本法によるホウ素の定量範囲は $0.02(5 \mathrm{~cm}$ 七ル) 10mg $/ 1$ (1 cm セル) であり, 高感度に精度よく分析できた。本法を排水扰よび環境 水に適用したところ,十分定量できることが判明した。 しかしながら，工場排水については，ホウ素がフッ化 物として存在している場合があるので, 本法に先立ち アルカリ融解する必要があった。

（原稿受理 昭和 60 年 6 月 14 日）

\section{引用文 献}

1) Matthews, P. J. (1974) A survey of boron content of certain waters of the greater London area using a nobel analytical method. Water Res., 8, $1021-1028$.

2）上杉勝弥, 山口茂六, 石原良雄（1980）アゾメチ ン $\mathrm{H}$ による海水, かん水扣よびにがり中のホウ素の 吸光光度定量, 日本海水学会誌, 34, 249-254.

3 ) James, W. D. (1982) Water-leachable boron from coal ashes. Environ. Sci. Technol., 16, 195 -197 .

4) Agazzi, E, J. (1967) Extraction-flame photometric determination of boron. Anal. Chem., 39, $233-235$. 
$5)$ Horta, A. M. T. C. and Curtius, A. J. (1978) Rapid extraction-atomic absorption determination of boron in sea water. Anal. Chim. Acta, 96, 207-210.

6 ) Spielholtz, G. I., Toralballa, G. C. and Willsen, J. J. (1974) Determination of total boron in sea water by atomic absorption spectroscopy. Mikrochim. Acta, 649-652.

7) E. P. A. (1979) Guidelines establishing test procedures for the analysis of pollutants ; Proposed regulations. Federal Register, 44, Mon. Dec. 3, 69558-69564.

8 ) Winge, R. K., Fassel, V. A., Kniseley, R. N., Dekalb, E. and Haas, W. J. Jr. (1977) Determination of trace elements in soft, hard, and saline waters by the inductively coupled plasma, multi -element atomic emission spectroscopic (ICP -MAES) technique. Spectrochim. Acta, 32B, 327 $-345$

9 ) 北村秀樹, 杉前昭好, 中本雅雄 (1984) 誘導結 合高周波プラズマ発光分析法による水中の微量ホウ 素の定量，水質污濁研究，7，23-29.

10）無機応用比色分析編集委員会編（1973） 無機応 用比色分析 1，248pp., 共立，東京.

11）工場排水試験方法 JIS K0102－1981，144pp., 日本 規格協会, 東京.

12) Ōshima, M., Motomizu, S. and Tōei, K. (1983) Solvent extraction spectrophotometric determination of boron with 3,5-di-tert-butylcatechol and ethyl violet. Anal. Chem., 56, 948-950.

13) Saito, S. and Uchikawa, S. (1984) Spectrophotometric determination of boron by solvent extraction with 2-hydroxy-2-methylbutyric acid and malachite green. Bunseki Kagaku, 33, E87-E93.

14）（1970）上水試験方法，260pp., 日本水道協会, 東 京.
15) Goulden, P. D. and Karkar, Y. P. (1976) Modified curcumin and dianthrimide methods for the determination of boron in the presence of high levels of nitrate and organics. Water Res., 10, 491 -495 .

16) Goldman, E., Taormina, S. and Castillo, M. (1975) A modified curcumin method for determining trace amounts of boron. J. Am. Wat. W. Assoc., Jan., 14-15.

17) Mair, J. W. Jr. and Day, H. G. (1972) Curcumin method for spectrophotometric determination of boron extracted from radiofrequency ashed animal tisssues using 2-ethyl-1,3-hexanediol. Anal. Chem., 44, 2015-2017.

18) Hayes, M. R. and Metcalfe, J. (1962) The boron -curcumin complex in the determination of trace amouts of boron. Analyst, 87, 956-969.

19) Uppström, L. R. (1968) A modified method for determination of boron with curcumin and a simplified water elimination procedure. Anal. Chim. Acta, 43, 475-486.

20) Dyrssen, D. W., Novikov, Y. P. and Uppström, L. R. (1972) Studies on the chemistry of the determination of boron with curcumin. Anal. Chim. Acta, 60, 139-151.

21) Uppström, L. R. and Östling (1976) The formation of rosocyanin in the presence of water. Anal. Letters, 9, 311-324.

22）北村秀樹，大川和伸，久下芳生，浅田真吾 (1978) クルクミン変法による工場排水捺よび海水中の微量 ホウ素の定量, 公害と対策, 14, 877-884.

23) Choi, W. W. and Chen, K. Y. (19779) Analysis of boron in water using an improved curcumin method. J. Am. Wat. W. Assoc., Mar. 153-157.

24）浅原照三，他 (1976） 溶剤ハンドブック，520pp., 講談社, 東京. 